Dialectologia 26 (2021), 145-178.

ISSN: 2013-2247

Received 9 April 2019.

Accepted 19 October 2019.

\title{
AGRICULTURAL TERMS IN RICE PRODUCTION: \\ A DIALECTOLOGICAL STUDY
}

\author{
R.A. Disyacitta NARISWARI \& Multamia R.M.T. LAUDER \\ Universitas Indonesia * \\ dnariswari@ymail.com / mia.lauder@gmail.com
}

\begin{abstract}
In the multilingual society of Indonesia, communication in agricultural settings is affected by variation in regional languages. This study used the methods of dialectology, isoglosses, and dialectometry to establish language boundaries and document variants of agricultural terms in three widely spoken languages in the Karawang Regency in West Java: Sundanese, Javanese, and Betawi Malay. The study addressed the challenge faced by agricultural advisors in the field of the communication gap between advisors and farmers. The advisors use Indonesian variants of agricultural terms, but farmers are familiar with terms in one of the other languages spoken in the area. This study detailed what languages are used in each village and illustrates a wealth of information on multiple variants in various languages for any particular agricultural term in Indonesian. The results will be of use to support improved yields in rice production.
\end{abstract}

Keywords

dialectology, agricultural terms, local languages, rice farming, communication in agriculture

\section{TÉRMINOS AGRÍCOLAS EN LA PRODUCCIÓN DE ARROZ: UN ESTUDIO DIALECTAL}

\section{Resumen}

En la sociedad multilingüe de Indonesia, la comunicación en entornos agrícolas se ve afectada por la variación en las lenguas regionales. Este estudio ha utilizado los métodos de la dialectología, isoglosas y de

\footnotetext{
* Department of Linguistics, Faculty of the Humanities, Universitas Indonesia. UI Campus, Depok 16424, Indonesia.
} 
la dialectometría para establecer límites lingüísticos y documentar variantes de términos agrícolas en tres idiomas ampliamente hablados en la regencia de Karawang en Java Occidental: el sundanés, el javanés y el betawi malayo. El estudio aborda el desafío que encuentran los asesores agrícolas a causa de la brecha de comunicación que se origina entre ellos y los agricultores. Los asesores utilizan variantes indonesias de términos agrícolas, pero los agricultores están familiarizados con los términos en uno de los otros idiomas que se hablan en el área. Este trabajo detalla qué idiomas se usan en cada aldea e ilustra una gran cantidad de información sobre múltiples variantes en varios idiomas para cualquier término agrícola en particular en indonesio. Los resultados son útiles para conseguir un mejor rendimiento en la producción de arroz.

\section{Palabras clave}

dialectología, términos agrícolas, lenguas locales, cultivo de arroz, comunicación en la agricultura

\section{Introduction}

This paper reports an applied study of the linguistics of communication in agriculture, using dialectological methods. It focused on a language barrier experienced by advisors when assisting Indonesian rice farmers in the field. It was indicated that the training was encountering a language barrier between the advisors and the farmers. The goal of this educational program was to assess the status of the farmers and their ricefarming practices and advise them on how to increase productivity. However, advisors found that communication on details of farming was not always smooth. The advisors were using Indonesian and some English, but they found that the farmers had difficulty understanding them. The farmers spoke vernaculars (bahasa daerah). The need for a glossary of farming terms for the languages used in areas where rice was grown became apparent.

Karawang Regency because it is the most important rice-growing area in West Java. However, to identify what words in particular were being used in what cases and at what locations, a geographical approach was required. It was decided to use dialectological methods. The goal was to gather a set of agricultural terms in the languages used in this area, but to do this, it was first necessary to map the languages in the area and their variants. Thus, information was gathered on sets of basic words, using the Swadesh list, as well as also a supplementary list of words, namely, agricultural terms. Dialectology was 
a useful source of methods here because the data it produces allow us to identify the language or languages that are spoken in the research area. Language maps were produced from the data to show where what languages are spoken and where the boundaries or overlapping territories are between languages. Variants within languages are also detected by this means. In this context, it was seen that a single agricultural term in English or Indonesian could have more than one translation equivalent in a given language, whether this was due to different pronunciations, the existence of two or more words, or other dialectical variation. This fact obviously has implications for the creation of a multilingual glossary where users might expect to find one-to-one equivalents between words for each language.

This study was conducted in Karawang Regency, located near Jakarta. It obtained data on basic words to create a language map of the area. Such a map is essential for the study and documentation of the agricultural terms in languages across the area. The data gathered on the agricultural terms were richer and more varied than initially expected. These products can provide the basis for the design of education and training materials for governmental training programs for rice growers all over the country. The result is expected to be able to bridge the communication gap and harmonize communication in a linguistically diverse country that also has an official national language. In the sphere of agriculture, better communication can serve the goal of improving rice productivity and lead to food sufficiency.

\section{Conceptual framework \& literature review}

\subsection{Rice cultivation in Indonesia}

Indonesia is a largely agrarian country; the agricultural sector is fundamental to its economic growth (Anderson, Stringer, Erwidodo \& Feridhanusetyawan 2009) and contributes the most to the gross domestic product. Rice production in Indonesia is fundamental in this sector (Truong \& Karim 2016) and has been cultivated in this area for 
around 3,000 years (Sharma 2010). Indonesia is the world's third largest producer of rice, with $8 \%$ of global production (Chauhan, Jabran \& Mahajan 2017; Smith \& Dilday 2003). However, Indonesia still imports rice, as rice is the main staple food, and Indonesia's population exceeded 250 million in 2015. Indonesia's Department of Agriculture has been working to increase rice production.

\subsection{Government policy on agriculture: Food security and the MDGs}

Rice production is considered a strategic issue for Indonesia because it involves food security and poverty reduction. These two issues form part of the UN's Millennium Development Goals (MDGs). Indonesia was relatively successful in achieving the MDGs. Contemporary understanding of the MDGs assesses a number of issues, such as the progress toward achieving them, discussed by McGillivray (2008); community initiatives in the Asia-Pacific region, investigated by Singh et al. (2013); poverty and agriculture, indicated by Bengtsson (2007) and Cimadamore et al. (2016); and in Feeny \& Clarke (2009), international assistance within the Asia-Pacific region. Information technologies and literacy play a role in reaching the MDGs, as found in Kaur \& Tao (2014). The MDGs were to have been reached in 2015 and have since been superseded by the Sustainable Development Goals (SDGs). The MDGs are assessed in relation to agriculture in Indonesia and SEA by Crowther et al. (2017) and Servaes (2016). Indonesia has passed legislation to support progress in this area. Food security in Indonesia is governed under Law no. 18 of 2012, on Food. The Department of Agriculture is implementing a nationwide education program to support farmers in optimizing their rice yields.

\subsection{Agricultural-Extension System for rice farmers}

This Agricultural-Extension System (AES) is post-secondary continuing education in agriculture, a kind of competence-based vocational training. Preston (2017) and Mulder (2016) give a general introduction to the program, and Arifin (2006) and Maiangwa et al. (2010) discuss agriculture-oriented training in Indonesia. 
The AES was designed to give farmers guidance and counselling in the field to help them address practical problems and to introduce improved methods of raising production. The program is called penyuluhan pertanian in Indonesian, which suggests the concept of advice or counselling given to farmers. We will refer to the trainers in this program as advisors. It plays an important role in helping farmers improve their yields by bringing suitable new ideas and technologies (Maiangwa et al. 2010).

The legislation regulating the AES is Law No. 16 of 2006, on an Extension System for Agriculture, Fisheries, and Forestry (Undang-undang No. 16 Tahun 2006 tentang Sistem Penyuluhan Pertanian, Perikanan dan Kehutanan). The law defines the goals, methods, recipients, and advisors for the program, among other things. The AES was drafted to produce farmers who are more capable and self-reliant and can run a farm that will support their family's welfare and contribute to the wider welfare of the community (Soekartawi 1988: 5).

The educational advisors for the AES draw from three pools. These are civil servants (pegawai negeri sipil), private-sector educational advisors, and self-help advisors. Civilservant advisors have the greatest authority to conduct the activities of the extension program. The private-sector advisors generally come from the business world and have experience in consulting. Self-help instructors are civic-minded individuals who volunteer their experience to help the program. Naturally, all advisors should have agricultural skills and experience in rice growing, but it is also important for them that they have good communication skills, as this is important in extension education (Nasution 1990).

\subsection{Communication in agriculture}

The present study concerns the communication of agricultural terms. This is evident in agricultural communication, a subject that covers a wide range of situations. Boone et al. (2000) looks at agriculture and communication from a critical perspective, and Eise \& Hodde (2016) suggest that insufficient attention is paid to that subject. There have also been linguistic studies of agricultural language, such as that of Raţă et al. (2012), as well 
as some treatments in encyclopaedias, e.g., van Alfen (2014). Much of this literature, however, focuses on agriculture as it is practiced in the developed West.

There have also been a significant number of specialist monolingual glossaries or dictionaries of agricultural terms, generally relating to Western or Indian contexts, where agriculture is as important as it is in Indonesia. See, for example, Kumar \& Shivey (2008), Lewis (2001), Mangaraj \& Ali (2015), Roseby (2006), Stachiw (2016), and Singh \& Singh (2004). Finally, there is also a trilingual dictionary of agricultural terms compiled in South Africa, featuring Afrikaans, English, and Xhosa (Department of Agriculture 2011).

The literature covers a number of issues, but it is clear that works on communication in agriculture and linguistic studies of agricultural language are few and far between. The above-mentioned trilingual dictionary from South Africa is the only example found of a dictionary of agricultural terms in a multilingual setting.

Few works in Indonesia are up to date. One early work that discusses agricultural communication in the Indonesian context and that centres the importance of agricultural communication in relation to the AES is Soekartawi (1988).

The success of the AES depends on the ability of the advisors to communicate with the beneficiary farmers. Arifin (2006) found that advisors or counsellors who work with farmers, though they may be well versed in rice production, tend to have problems communicating with them. The first language of the farmers is generally not Indonesian. Because the advisors generally use Indonesian and some English, a language barrier exists between the groups.

One solution to this would be language training for either the farmers or the advisors, but huge pragmatic constraints would limit the application of this approach: time, available resources, and cost are all restrictive factors. A quicker and less costly way to help would be to provide glossaries of agricultural terms in the languages that the farmers speak to the advisors. This would also present challenges, not least because of the large number languages spoken in Indonesia.

To assess what languages are spoken in Karawang Regency, we turn to the dialectology literature on language variation in that area. 


\subsection{Overview of Karawang Regency}

Karawang Regency (kabupaten) is located in West Java, Indonesia, and its capital city is also called Karawang. It is east of Jakarta and has an area of $1,753,27 \mathrm{~km}^{2}$, or $175,327 \mathrm{ha}$, and a population of 2,127,791, according to the 2010 census, with a density of 1,288 people per $\mathrm{km}^{2}$. The latest official estimate (January 2014) of the population is 2,288,254. Karawang Regency borders Bekasi and Bogor Regencies to the west, the Java Sea to the north, Subang Regency to the east, Purwakarta Regency to the southeast, and Cianjur Regency to the south. Karawang Regency's location on the eastern outskirts of metropolitan Jakarta, just outside the Jabodetabek (Jakarta-Bogor-Depok-TangerangBekasi) region, has aided its industrial growth. Industry continues to grow in the regency, as new factories are built by domestic and multinational companies. However, Karawang Regency is also a major rice production area.

\subsection{Languages spoken in Karawang}

Previous dialectological research has shown that there are three main languages spoken in Karawang. Further, the spatial distribution and variation within languages are also revealed, as well as the changes to the distribution over time.

In Karawang Regency, the majority of the population speaks Sundanese. Sudjana et al. (1983, pp. 91-92) identified three varieties or dialects of Sundanese: northern, western, and standard. Yudibrata et al. (1990) studied the use of Sundanese in Karawang Regency, finding that Sundanese in use had both standard and dialect forms. Subsequently, Suminarsih (1996) conducted a comprehensive language-mapping study to identify all regional languages used throughout the Karawang Regency. This study determined that three main languages were used: Sundanese, Javanese, and Betawi Malay, a Malay-based creole spoken by the Betawi people. More recent studies have confirmed the presence of these three languages (Dasika 2011). This paper is based on field work done in 2014, some results of which were published in Nariswari (2015). 
Although a number of studies of language use in the area have been published, there may have been changes in the geographical distribution of languages in Karawang Regency, and it is essential to have the most up-to-date data. In fact, it was found that there had been a change, so this study does produce better accurate data on agricultural terms than had previously been available.

\section{Research question \& objectives}

Two research questions were posed: 1 . What languages are used in the area and specifically where? This is pursued using the Swadesh list of basic words. 2. What are the agricultural terms used in each of the different languages identified, in the particular areas? The objective for the first question was to produce an-up-to date map of language areas to show any changes from previous research, and in response to the second question, the objective was to produce a comprehensive glossary or word list of translations for each of the agricultural terms elicited in the questionnaire.

\section{Methods}

\subsection{Dialectology}

To address the question of what agricultural terms are in use in Sundanese, Javanese, and Betawi Malay as spoken in Karawang Regency, it was necessary to first determine what villages or areas those languages are spoken in. This was pursued through dialectology research and field linguistics to identify geographical variations. This method allowed the creation of language maps that show different language areas.

The literature on dialectology gives a clear picture of well-established methods and the principles behind those methods. The literature supporting the approach of this study included both international and local sources, such as Chambers \& Trudgill (2004), Ayatrohaedi (2003) and Lauder (1993, 2007). Certain important elements and particular 
decisions made during the study that impact on reliability and validity of the findings are given below.

\subsection{Reasons for the choice of Karawang Regency}

Karawang Regency was chosen for the research site because it is a centre of rice production in West Java. Rice farming is the largest occupation in the area. This can be seen in the amount of land used for rice production. Rice fields are 97,529 ha, $55.62 \%$ of the entire area of Karawang Regency. The regent (bupati) of Karawang acknowledges the importance of food crops, horticulture, fisheries, and livestock in the regency. He also notes that the area could be made even more productive by the National Rice Production Enhancement Program.

\subsection{Sampling and selection of villages}

The determination of the sources of data required a decision on the number of villages to investigate and where they should be sought. Data were gathered on 50 villages located in 30 districts. The village selection took into account the relative productivity of the districts. This was considered important because of the relationship between advanced agricultural methods, technology, and high production (Priyanto 1997). There may also be a relationship between high productivity and the ability of farmers to understand agricultural terms for innovative tools and methods. Districts were classified as either high, average, or low productivity. In all, 20 villages were chosen in high- and 20 in low-productivity areas, with the remaining 10 being in averageproductivity areas. Once the villages were identified, the selection was revised, based on referrals from the Head of Technical Implementation Unit of the Agriculture Service and the Head of the Agriculture, Fisheries and Forestry Extension Agency in each subdistrict. Once this was done, a basal map was produced. 


\subsection{Selection of informants}

The informants in this study were all local rice farmers. Two informants were chosen for each observation point, for a total of 100 informants. The requirements for being an informant were a) middle aged and free from dementia; b) literate, with average educational attainment, such as completion of junior high school or high school; c) born and grew up in the area; d) native speaker of the main language or dialect of the area, fluent, and able to communicate; e) not widely travelled, with relatively little chance to communicate with people speaking other languages or varieties, or at least not affected by such contacts (Ayatrohaedi 2003: 39-40). Gender was also taken into consideration. A division of labour in agriculture existed in the area, with men and women doing different, complementary jobs. Preparatory work was done by men; planting and maintenance were done by women; and the harvest and post-harvest stages were completed by both women and men. For this reason, for each village, one of the two informants was a man, and the other was a woman.

\subsection{Questionnaire}

The questionnaire had two sections: 1 ) a list of 200 basic words called the Swadesh list and 2) a list of 125 agricultural terms. The responses elicited from the basic word list were used to conduct an analysis of isoglosses and dialectometry. Bundles of isoglosses on the isogloss maps show where language boundaries fall. By this means, it is also possible to make maps that provide empirical, quantifiable measures of the degree of similarity or dissimilarity between neighbouring villages.

The list of agricultural terms list was used to identify local variants of agricultural words. This list included terms for the preparation, planting, maintenance, harvesting, and after harvest of rice. It also included terms for tools used and pests of the rice plants. 
Dialectologia 26 (2021), 145-178.

ISSN: 2013-2247

\section{Results}

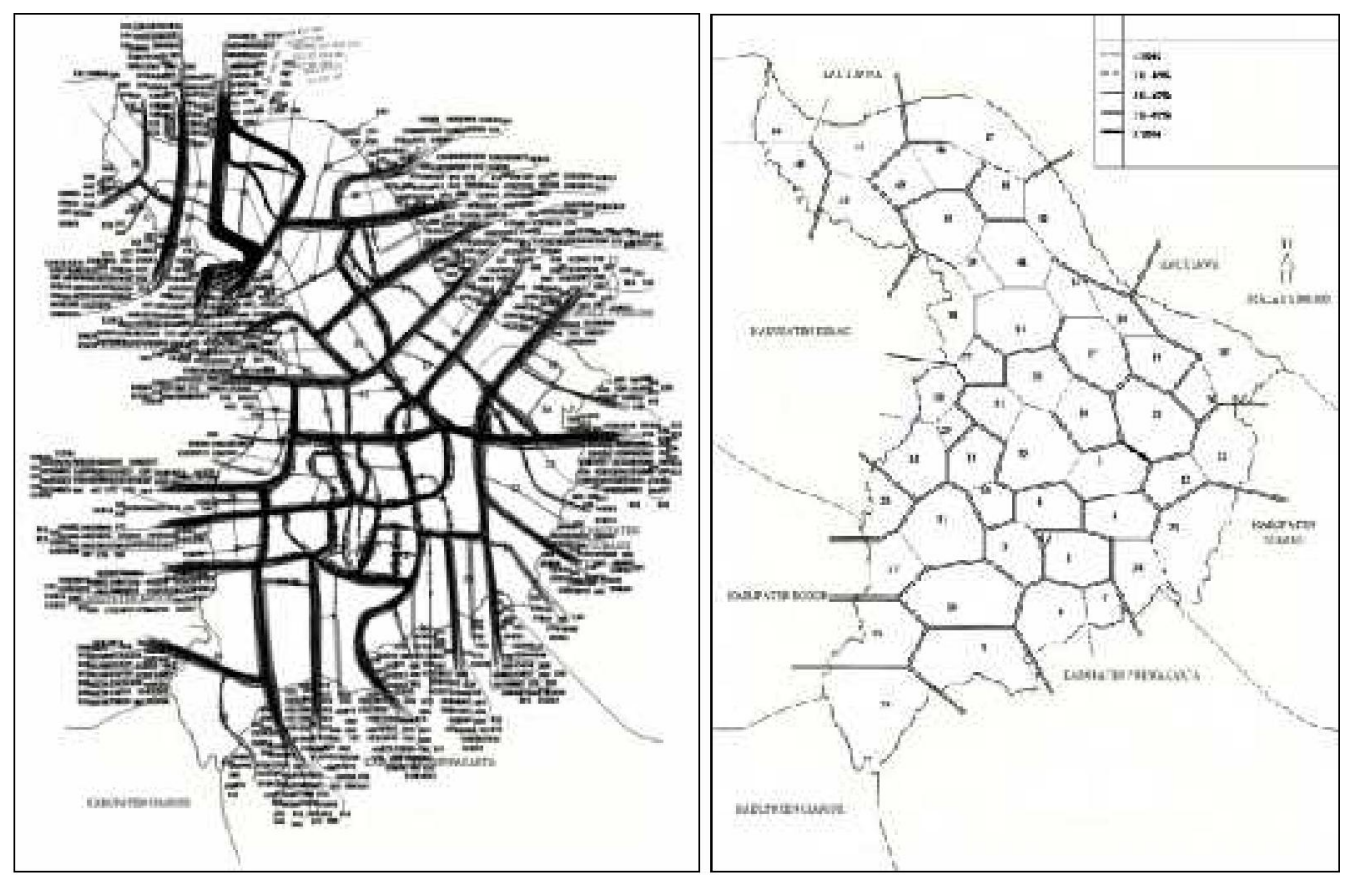

Figure 1. Isogloss bundle map (left) and dialectometric results map (right). Mapping results.

The isogloss analysis and dialectometry (Figure 1) lead to one conclusion. The pattern of isoglosses and the number of double lines in the dialectometry suggest the presence of a very high amount of language variation in the study area. This is due to lexical innovation and depends on the farmer's level of knowledge. This degree of variation may also have been influenced by the contact that farmers have with agricultural-extension advisors and other farmers. The findings reported here can be compared to those of Fakoya et al. (2012). 


\subsection{Findings on language areas}

\begin{tabular}{|l|l|}
\hline Village name & No. \\
\hline Cengkong & 1 \\
\hline Sukasari & 2 \\
\hline Pancawati & 3 \\
\hline Blendung & 4 \\
\hline Karangtanjung & 5 \\
\hline Karangjaya & 6 \\
\hline CikampekPusaka & 7 \\
\hline Dawuan Tengah & 8 \\
\hline Kutapohaci & 9 \\
\hline Kutamekar & 10 \\
\hline Puserjaya & 11 \\
\hline Purwadana & 12 \\
\hline Plawad & 13 \\
\hline Lamaran & 14 \\
\hline
\end{tabular}

\begin{tabular}{|l|l|}
\hline Village name & No. \\
\hline Malajaya & 15 \\
\hline Kalisari & 16 \\
\hline Pegadungan & 17 \\
\hline Tempuran & 18 \\
\hline North Kiara & 19 \\
\hline Jayamukti & 21 \\
\hline North Cicinde & 22 \\
\hline Mekarsari & 23 \\
\hline Wancimekar & 24 \\
\hline WargaSetra & 25 \\
\hline Cintaasih & 26 \\
\hline Mekarmulya & 27 \\
\hline Karangligar & 28 \\
\hline Tanjungmekar & 29 \\
\hline
\end{tabular}

\begin{tabular}{|l|l|}
\hline Village name & No. \\
\hline Tanjungpura & 30 \\
\hline Kutawargi & 31 \\
\hline Sukamerta & 32 \\
\hline Sindangmukti & 33 \\
\hline Sukaratu & 34 \\
\hline DukuhKarya & 37 \\
\hline Amansari & 38 \\
\hline Jaya Makmur & 39 \\
\hline Ciptamarga & 40 \\
\hline Payung Sari & 41 \\
\hline Tambak Sari & 45 \\
\hline TambakSumur & 46 \\
\hline Pajaten & 47 \\
\hline
\end{tabular}

Table 1. Sundanese

\begin{tabular}{|l|l|}
\hline Village name & No. \\
\hline BayurKidul & 20 \\
\hline Mekar Maya & 35 \\
\hline Tegalwaru & 36 \\
\hline Puspa Sari & 42 \\
\hline Cibuaya & 48 \\
\hline
\end{tabular}

Table 2. Javanese

\begin{tabular}{|l|l|}
\hline Village name & No. \\
\hline Karyabakti & 43 \\
\hline Baturraden & 44 \\
\hline Teluk Jaya & 49 \\
\hline Tanah Baru & 50 \\
\hline South Kiara & 19 \\
\hline
\end{tabular}

Table 3. Betawi Malay 


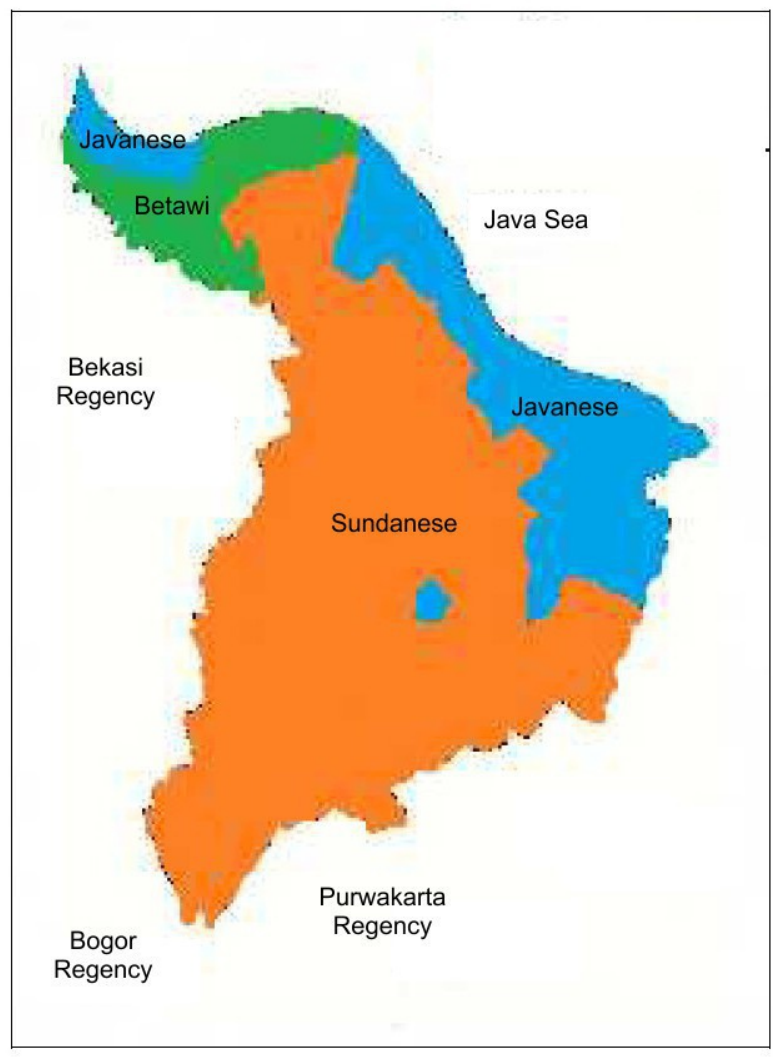

Suminarsih (1996)

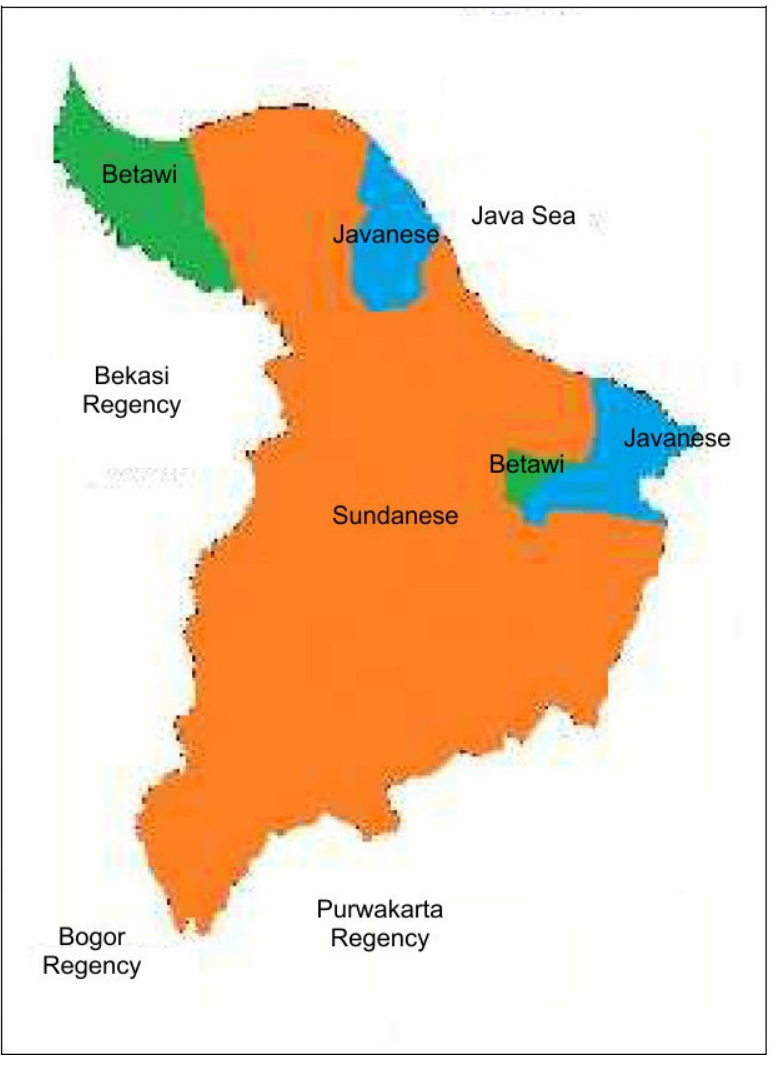

Nariswari (2014)

Figure 2. Comparison of language areas over time (Language maps for Karawang Regency: L, 1996; $R, 2014)$.

Figure 2 allows us to compare the spatial distribution of languages in Karawang in 1996 with the same area in the data from our study, in 2014. The most notable change is that the Javanese areas have shrunk and have been replaced by Sundanese. This has happened in two areas in particular, on the coast and in the east. Another interesting finding is the appearance of a small Betawi Malay-speaking area in the centre of the map and the disappearance of a small Javanese isolate area in the centre. This may be the result of intensive language contact from Sundanese areas, together with coast-bound migration. This type of language change may be due to economic growth, industrialization, or improvements in transportation, among other factors that can stimulate an influx of people from outside an area. This produces language contact between locals and newcomers. This makes migration a likely factor in language change. 


\subsection{Variation in agricultural terms}

An analysis of agricultural terms in Sundanese, Javanese, and Betawi Malay shows striking patterns of variation. First, there are agricultural terms for which no farmer in any village in any of the language areas could find a local-language equivalent. There are also agricultural terms whose equivalents in Sundanese, Javanese, and Betawi Malay are the same or similar. Next, there are agricultural terms which are similar in pairs of language areas, for example the same in Sundanese and Javanese villages, but not in Betawi Malay, and the same can be true in Sundanese and Betawi Malay villages or between Javanese and Betawi Malay-speaking villages. Finally, there are agricultural terms that are used only in villages in one language area, whether just Sundanese, Javanese, or Betawi Malay.

However, one phenomenon that was found in many places was the rarity for a single term in Indonesian to correspond to a single term in Sundanese, Javanese, or Betawi Malay. A single agricultural term in Indonesian is likely to have a number of translations in a given language. Frequently, a large number of variants are found in a regional language, as many as 10 or 15 in some cases. We also note that each village may have its own distinctive term. In Table 2, some examples of these distinctive patterns of variation can be seen.

\begin{tabular}{|l|l|l|l|l|l|}
\hline No. & Indonesian & English & Sundanese & Javanese & Betawi Malay \\
\hline $074 p$ & TRAKTOR BESAR & big tractor & - & - & - \\
\hline $079 p$ & ALAT UKUR HUJAN & $\begin{array}{l}\text { ombrometer, } \\
\text { rain gauge }\end{array}$ & - & - & - \\
\hline $083 p$ & $\begin{array}{l}\text { PEMBABAT BATANG } \\
\text { PADI }\end{array}$ & rice stem cutter & - & - & - \\
\hline
\end{tabular}

Table 2. Terms for which there were no local-language equivalents in any of the three languages.

The terms TRAKTOR BESAR 'big tractor', ALAT UKUR HUJAN 'rain gauge', and PEMBABAT BATANG PADI 'rice stem cutter' were not recognized by any of the farmers, whether they spoke Sundanese, Javanese, or Betawi Malay. These terms have no local equivalent because they refer to concepts and technologies that are unfamiliar to the farmers in Karawang Regency. The AES is in part intended to identify and share new 
means by which farmers can improve their productivity. These findings thus highlight the technologies that require explanation and that could be introduced to help achieve production goals.

\begin{tabular}{|l|l|l|l|l|l|}
\hline No. & Indonesian & English & Sundanese & Javanese & Betawi Malay \\
\hline $2 p$ & SAWAH & rice field & sawah & sawah & sawah \\
\hline $10 p$ & MENCANGKUL & hoeing & macul & macul & macul \\
\hline $13 p$ & MENGAPURI & liming & ngapur & ngapur & ngapur \\
\hline
\end{tabular}

Table 3. Matching terms among Sundanese, Javanese, and Betawi Malay.

Table 3 provides three terms for which farmers speaking Sundanese, Javanese, and Betawi Malay have the same term for.

\begin{tabular}{|l|l|l|l|l|l|}
\hline No. & Indonesian & English & Sundanese & Javanese & Betawi Malay \\
\hline $14 \mathrm{p}$ & MEMUPUK & fertilize & ngagemuk & ngagemuk & ngegemuk \\
\hline & & & nggemuk & nggemuk & tebar \\
\hline & & & ngarabuk & ngarabuk & ngorea' \\
\hline & & & mupuk & ngorea' & ngawur \\
\hline & & & ngawur & - & - \\
\hline
\end{tabular}

Table 4. Matching and variant terms.

The agricultural term MEMUPUK 'fertilize' shows a distinctive pattern of variation, being translated by both similar and different terms in the local languages. Further, in villages that speak the same language, the term used may be different. For instance, Sundanese, Javanese, and Betawi Malay farmers used ngagemuk, ngegemuk, and nggemuk, respectively. This is the same term, although there is a slight difference in pronunciation. However, this term is also used in a variety of variants. For instance, both Sundanese and Javanese farmers used the variant ngarabuk. There is also an example of exactly the same term being used by Betawi Malay and Javanese farmers, ngorea', as wells as a term shared by Sundanese and Betawi Malay farmers, ngawur. Finally, mupuk one term is only in Sundanese, and tebar is only used in Betawi Malay. 


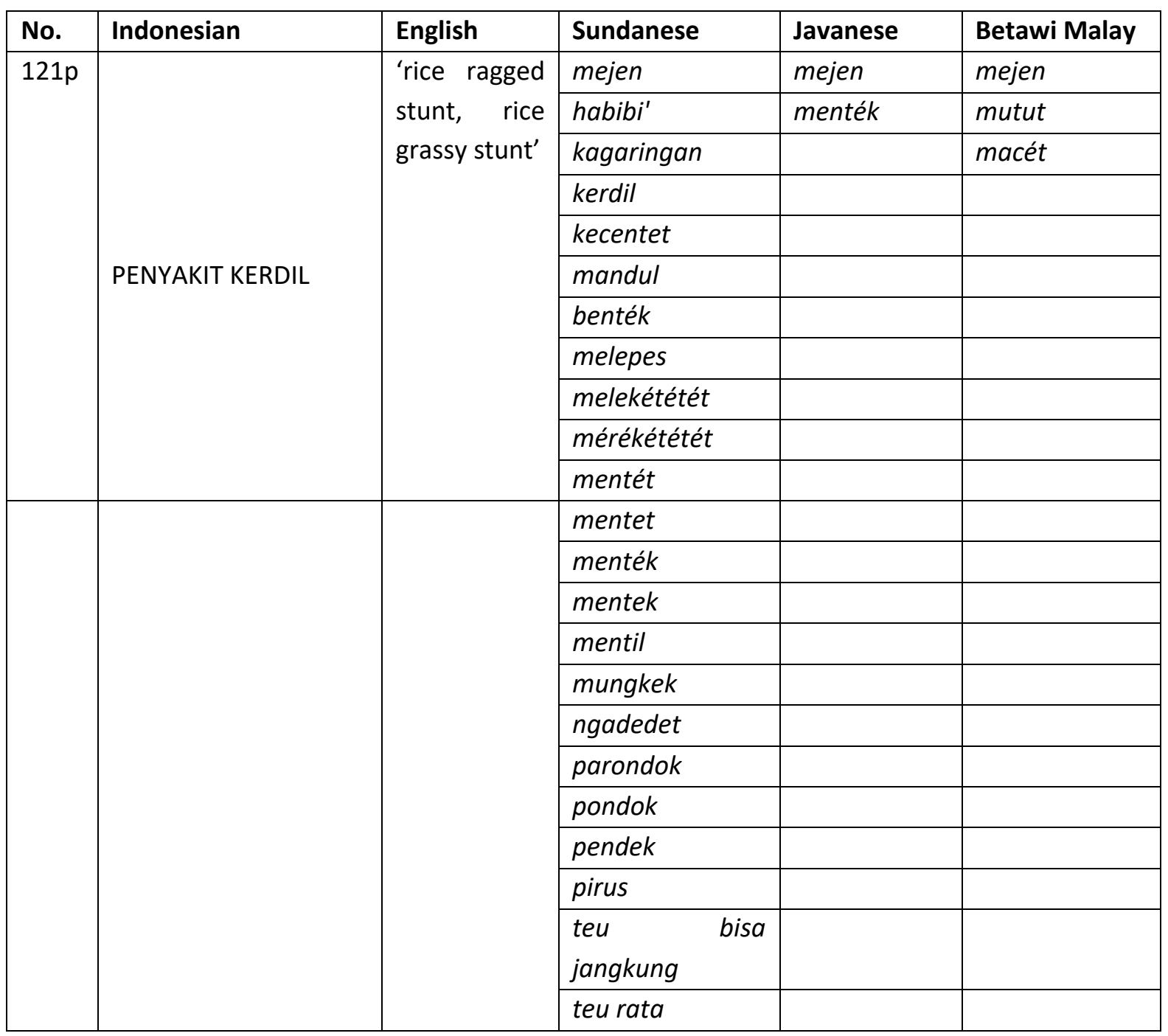

Table 5. Terms with a high level of variation.

The agricultural term PENYAKIT KERDIL 'rice ragged stunt, rice grassy stunt', is translated by mejen in Sundanese, Javanese, and Betawi Malay villages (Table 5). In Javanese-speaking villages, only two forms were found, mejen and menték. In Betawi Malay-speaking villages, three variants were found, mejen, mutut, and macét. However, quite notably, there were a very large number of variants in Sundanese-speaking villages: mejen, habibi', kagaringan, kerdil, kecentet, mandul, benték, melepes, melekététét, mérékététét, mentét, mentet, menték, mentek, mentil, mungkek, ngadedet, parondok, pondok, pendek, pirus, teu bisa jangkung, and teu rata. 
These variations in local-language forms for agricultural terms in Karawang Regency show that when there are difficulties in communicating on agricultural issues, advisors should not assume that a single translation equivalent will work for an Indonesian language term in a given vernacular. In fact, it is quite likely that there will be a number of variant terms. In cases where this is true, it may be concluded that farmers are familiar with the term and the accompanying idea. Cognitively and culturally, it can be considered part of their daily life. This is reflected in the diverse forms of the word that emerge in such cases. A kind of lexical innovation is thus seen that reflects the farmer's relationship with the concepts referred to by the given terms. Part of this variation may be the drive to express individual, local identities compared to neighbouring villages or areas. In some cases, etymological study of the local term may reveal interesting semantic processes. Overall, diverse patterns are part of the identity for each village.

\subsection{Gender and language}

This study was conducted using both women and men as informants, due to the consideration that there may be variation in the use of agricultural terms between genders. The results of the analysis of agricultural terms did not support this assumption: men and women used the same agricultural terms.

\section{Conclusion}

The study pursued two research questions. 1 . What languages are used in the area and specifically where? This is pursued using the Swadesh list of basic words. Three languages were found to be in use: Sundanese, Javanese, and Betawi Malay. This matched the findings of a number of earlier studies. However, changes in distribution of the languages had appeared in where the languages were spoken. The use of Sundanese had expanded and so had Betawi Malay. Javanese-speaking areas had diminished, and in 
some places, they had disappeared entirely, replaced either by Sundanese or Betawi Malay. The explanation for this was migration. It was also found that a good deal of variation in vocabulary was found. The explanation for this was language contact.

2. What are the agricultural terms used in each of the different languages identified, in the particular areas? Many agricultural terms were collected for the three languages. There was variation, as expected, among the languages, but variants were also often found within them as well, with some terms having as many as 10 or 15 regional language equivalents.

This study was intended to produce a comprehensive glossary or word list of terms in local languages for each of the rice-farming terms elicited. The word list is given as a short dictionary of agricultural terms, with the entries given for each term, as follows: headword in Indonesian and English translation, followed by all lexical variations, first for Sundanese, then Javanese, and finally Betawi Malay (Appendix).

This word list will be of practical use for the Agricultural Extension and Development Agency as it prepares materials to support its advisors. Some familiarity with the terms will aid work in agricultural communication in rural areas. The resource created will also bear on advisor selection, favouring those who have spoken communicative competence in the language spoken by the farmers they will be working with.

Thanks to this study, we know that advisors intending to work at any of the following sites, namely, Batujaya Subdistrict (TP 43 and 44), Pakisjaya Subdistrict (TP 49 and 50), or certain parts of Cilamaya Kulon Subdistrict (TP 19) will be better equipped if they spoke Betawi Malay. Those intending to work in Cilamaya Wetan District (TP 35 and 36), Cilamaya Kulon Subdistrict (TP 20), Pedes Subdistrict (TP 42), or Cibuaya Subdistrict (TP 48) should be able to speak Javanese. For all other subdistricts in Karawang Regency, the advisors selected should be Sundanese speakers.

For competence levels in the target languages are too low or unavailable, the glossary of key terms, at very least, can be used with farmers to facilitate communication and ensure that key concepts are understood. Advisors should be familiar with the key terms in the relevant language. 
This study constitutes the first step in a larger application of language research to problems in agricultural development. First, it is part of a process to produce knowledge and reference works that can be used to assist agricultural trainers in their communications with farmers. Next, the work described here will help identify agricultural terms in local languages. The method used here can serve as a blueprint and be rolled out across all rice growing areas throughout Indonesia and to serve all of its many languages. The means employed by this study are not restricted to rice agriculture, but can be used for other types of agriculture as well. The goal of this work is to help the country achieve independence in the agricultural sector. Dialectology is a necessary first step owing to the widespread migration of different language groups, which results in high degrees of variation and changes in the boundaries of language areas. The method used here is capable of dealing with the high degree of variation in languages found in Indonesia, which has the second highest number of languages spoken within its borders of all the countries in the world.

The present study focuses on just one rice-growing area. It would be feasible to extend this work to other important rice-growing areas. Other languages besides Sundanese, Javanese, and Betawi Malay are spoken in other rice-growing areas. The research methodology used here has been shown to properly address the questions posed and so could be rolled out in a nationwide study. This would result in a comprehensive national glossary of rice agriculture terms in regional languages. This initiative would certainly contribute to the task of increasing rice production throughout the country, thus also contributing to the MDGs and the SDGs. It could also be imitated in other ASEAN countries, where dominant crops growing, and linguistic conditions are similar to those of Indonesia. 


\section{References}

Anderson, K., R. Stringer, ERWIDOdo, \& T. FeridhanUSETYAWAN (eds.) (2009) Indonesia in a Reforming World Economy: Effects on Agriculture, Trade and the Environment (reprint ed.), Adelaide: University of Adelaide Press.

ARIFIN, M. (2006) “Profil Kemampuan Umum (Generic Competencies) yang Diperlukan Bagi Penyuluh Pertanian", Jurnal Ilmu-ilmu Pertanian, 2(1), 50-64.

Ayatrohaed (2003) Pedoman Penelitian Dialektologi. Jakarta: Pusat Bahasa, Departemen Pendidikan Nasional.

BENGTSSON, B. M. I. (2007) Agricultural Research at the Crossroads: Revisited Resource-poor Farmers and the Millennium Development Goals, Enfield, NH: Science Publishers.

BOONE, K., T. MeISEnBACH \& M. A. TUCKER (2000) Agricultural Communications: Changes and Challenges, lowa: lowa State University Press.

ChAMBERS, J. K. \& P. TRUdgiLl $\left(2004^{2}\right)$ Dialectology, Cambridge \& New York: Cambridge University Press.

Chauhan, B. S., K. Jabran \& G. MAhajan (eds.) (2017) Rice Production Worldwide, New York: Springer Science+Business Media.

Cimadamore, A. D., G. Koehler \& T. Pogge (eds.) (2016) Poverty and the Millennium Development Goals: A Critical Look Forward, London: Zed Books.

Crowther, D., S. SeIfI \& A. Moyeen (eds.) (2017) The Goals of Sustainable Development: Responsibility and Governance, Singapore: Springer.

DASIKA, L. (2011) "Mengenal Karawang Lebih Dekat". [Retrieved from <http://lomardasika.blogspot.com/2011/08/mengenal-karawang-lebih-dekat.html>.]

DePartMent of Agriculture (2011²) Trilingual Agricultural Dictionary: Afrikaans, Isixhosa, English, Elsenberg, South Africa: Department of Agriculture, Provincial Government of the Western Cape.

EISE, J. \& W. HODDE (2016) The Communication Scarcity in Agriculture, Oxford: Routledge.

FAKOyA, E. O., H. A. BOdunde \& R. O. COKER (2012) “Assessment of Dialect Use in Agricultural Message Dissemination in Ogun State, Nigeria", OIDA International Journal of Sustainable Development, 4(10), 49-58.

FeEny, S. \& M. Clarke (eds.) (2009) The Millennium Development Goals and Beyond: International Assistance to the Asia-Pacific, Basingstoke: Palgrave Macmillan. 
Dialectologia 26 (2021), 145-178.

ISSN: 2013-2247

KAUR, H. \& X. TAO, X. (eds.) (2014) ICTs and the Millennium Development Goals: A United Nations Perspective, New York: Springer.

KUMAR, D. \& Y. S. SHIVEY (2008) Definitional Glossary of Agricultural Terms, New Delhi: I. K. International Publishing House.

LAUder, M. R. M. T. (1993) Pemetaan dan Distribusi Bahasa-bahasa di Tangerang, Jakarta: Pusat Pembinaan dan Pengembangan Bahasa.

LAUdER, M. R. M. T. (2007) Sekilas Mengenai Pemetaan Bahasa, Jakarta: Akbar Media Eka Sarana.

LEWIS, R. A. (2001) CRC Dictionary of Agricultural Sciences, Boca Raton, FL: CRC Press.

Maiangwa, M. G., R. A. OMolehin, O. B. AdeniJi \& U. S. Mohammed (2010) “Food Insecurity: Challenges of Agricultural Extension in Developing Countries", Journal of Agricultural Extension, 14(2), 73-105.

MangaraJ, S. \& N. Alı (2015) Concepts and Terminology in Agricultural Processing, New Delhi: Satish Serial Publishing House.

McGillivray, M. (2008) Achieving the Millennium Development Goals, London: Palgrave Macmillan. MULDER, M. (ed.) (2016) Competence-based Vocational and Professional Education: Bridging the Worlds of Work and Education, Cham, Switzerland: Springer International Publishing.

NARISWARI, R. A. D. (2015) Variasi Bahasa dan Istilah Pertanian di Kabupaten Karawang: Sebuah Kajian Dialektologi (Magister Humaniora pada Program Studi Linguistik Tesis Magister Humaniora), Universitas Indonesia, Depok.

NASUtION, Z. (1990) Prinsip-prinsip Komunikasi untuk Penyuluhan, Jakarta: Fakultas Ekonomi Universitas Indonesia.

PRESTON, J. (2017) Competence Based Education and Training (CBET) and the End of Human Learning: The Existential Threat of Competency, Cham, Switzerland: Springer International Publishing.

Priyanto, A. (1997) “Penerapan Mekanisasi Pertanian”, Jurnal Keteknikan Pertanian, 11(1), 54-58.

RATĂ, G., F. SALA \& I. SAMFIRA (eds.) (2012) Agricultural English, Newcastle upon Tyne: Cambridge Scholars Publishing.

ROSEBY, P. (2006) Dictionary of Agriculture, London: A \& C Black Publishing.

SERVAES, J. (ed.) (2016) Sustainable Development Goals in the Asian Context, Singapore: Springer Nature.

SharmA, S. D. (ed.) (2010) Rice: Origin, Antiquity and History, Boca Raton, FL \& Enfield, NH: CRC Press \& Science Publishers. 
Singh, A., E. T. Gonzalez \& S. B. Thomson (eds.). (2013) Millennium Development Goals and Community Initiatives in the Asia Pacific, New Delhi, India: Springer.

SINGH, A. K. \& N. P. SINGH (2004) Agricultural Terminology, New Delhi: Concept Publishing Company.

SMITH, C. W. \& R. H. DILDAY (eds.) (2003) Rice: Origin, History, Technology, and Production, Hoboken, NJ: John Wiley \& Sons.

SOEKARTAWI (1988) Prinsip Dasar Komunikasi Pertanian, Jakarta: Penerbit Universitas Indonesia (UI Press).

STACHIW, M. (2016) Agriculture Dictionary: Terminology of the Agriculture Industry, North Charleston, SC: CreateSpace Independent Publishing Platform.

Sudjana, A. S. H., A. MarzukI, A. Abas \& R. Jayawiguna (1983) Struktur Bahasa Sunda Pesisir Utara Jawa Barat, Jakarta Pusat Pembinaan dan Pengembangan Bahasa, Departemen Pendidikan dan Kebudayaan.

SUMINARSIH, W. (1996) Penelitian Geografi Dialek di Kabupaten Karawang: Kajian Geografi Dialek, (S1 Skripsi Sarjana Sastra), Universitas Indonesia, Depok.

Truong, T.-D. \& K. Karim (2016). The South China Sea and Asian Regionalism: A Critical Realist Perspective, Cham, Switzerland: Springer International Publishing.

VAN Alfen, N. K. (ed.) (2014) Encyclopaedia of Agriculture and Food Systems, London: Elsevier Science.

YUDibRATA, K., S. HIDAYAT \& O. RAHMAN (1990) Geografi Dialek Bahasa Sunda di Kabupaten Karawang, Jakarta, Departemen Pendidikan dan Kebudayaan. 


\section{Appendix}

\section{Multilingual Word List of Agricultural Terms Produced Through the Research}

TANAH 'ground, soil'

Sundanese: taneuh, leutak

Javanese: taneuh, lemah

Betawi Malay: tanah

SAWAH 'rice/paddy field'

Sundanese: sawah, sérang

Javanese: sawah

Betawi Malay: sawah

PEMATANG 'embankment, dike'

Sundanese: galengan

Javanese: galeng, galengan

Betawi Malay: galeng

PARIT 'ditch, trench'

Sundanese: jajaran, kakalenan, kamalir, kocoran, kokocoran, pacor, saluran, susukan, solokan

Javanese: bobolan, kocoran

Betawi Malay: kocoran, krowokan, solokan

LAHAN BERA 'fallow land'

Sundanese: bebera, bera, dangkal, garung, lahangadu', tegal, tegalan

Javanese: garung

Betawi Malay: bera, beréh, kebon

KULTIVASI 'cultivation'

Sundanese: gawéan, digawéan, nggawéan, ngagarap, digarap, garap, garapan, ngagaraptaneuh, ngagaraplahan, ngolah, mengolah, diolah, ngolahlahan, ngolahtaneuh, keurneraktor, nyambut

Javanese: gawéléléran, menggawé, ngolah Betawi Malay: digarap, ngerja'inlahan, ngolah, garaplahan, ngolahlahan

\section{MEMBERSIHKAN 'soil sterilisation'}

Sundanese: agonan, ngagonan, babad, ngebabad, ngababad, dibabat, bebersih, dibersihkeun, dibersihan, ngabersihan, cabut, koréd, ngoréd, dikorét, nyaangan, ngalélér, rambét, ngarambét, ngerambét Javanese: babad, namping, ngagonan, ngagoni

Betawi Malay: ngagonin, ngoréd

MENGGARU 'harrowing'

Sundanese: garu', ngagaru', ngegaru', digaru', ngagarok, digarok, ngegarok, gasrok, ngagasrok, ngegacok, garpu', neléktor, ngalélér, ngarambét

Javanese: digaru', ngegarok, nggarok, garokan

Betawi Malay: garu', ngagaru'

MEMBAJAK 'ploughing'

Sundanese: ngawuluku', ngaluku', neléktor, ngaléktor, ngabota', nyambut, singkal, nyingkal, dibedah, macul, ngagawéan, mimiti, ngolah

Javanese: neléktor, ngaléktor, ngeléktor, singkal, macul

Betawi Malay: ngaléktor, neléktor, luku'

\section{MENCANGKUL 'hoeing'}

Sundanese: macul

Javanese: macul

Betawi Malay: macul, pacul

MENGGEMBURKAN 'overturn the soil'

Sundanese: diipuk, dilepa', dipacul, dipaculan, disingkal, macul, gelebeg, kaléktor, ledog, nanglér, neliyek, ngabota', ngabuligag, ngagemburkeun, 
ngalelemah, ngalemeskeun, ngamontogkeun, nyorong, nyuburkeun, riduh, supayariduh, ngariduh, wuluku' Javanese: gemburaken, digarok, digarokgarok, disingkal, neliyek

Betawi Malay: menggemburkan, paculpacul, neléktor, singkal, menggemburkan, diamong, digaru', diguwar

\section{MERATAKAN PERMUKAAN TANAH \\ 'flattening the soil' \\ Sundanese: ngararata', ngararata, diratakeun, dirarata', dirata'-rata', ngaratakeun, ngerata, nguluku', garu, dodorong, didorong, ngadorong, ngadorong-dorongtaneuh, nanglér, ngalélér, ngérédan \\ Javanese: ditariki, gerabag, léléran, ngerata'}

Betawi Malay: ngelepa', ngerata'in

\section{MENGAPURI 'liming'}

Sundanese: ngapur, dikapur, ngawur, ngawurapu', ngawurkapur, ngaurinkapur, ngawurkeunkapur, awurankapur, diawur, méré' kapur, dibéré' kapur, diapu', ngagemuk, dikaptan

Javanese: ngapur, dikapur, ngawurapu', ngawurkapur

Betawi Malay: ngapur, ngaurinkapur

\section{MEMUPUK 'fertilize'}

Sundanese: mupuk, ngagemuk, nggemuk, ngarabuk, ngawur

Javanese: ngagemuk, nggemuk, ngarabuk, ngorea'

Betawi Malay: ngawur, tebar, ngegemuk, ngorea'
MEMETAKKAN 'plotting the soil for planting'

Sundanese: ngagaléng, digaléng-galéng, digaléngkeun, nyieungaléngan, dilongkrang, néhel, diroeh, naplak, neplak, nyaplak, ditaplak, ngubin, kotakan, sakotak-sakotak, dikotaksakotak, nyieunkotakan, pétakan, pétakpétak

Javanese: naplak, néhel, sepétak-sepétak

Betawi Malay: petakan, néhel, penggel, petakan

\section{DRAINASE 'drainage'}

Sundanese: solokan, sekundér, susukan, kocoran, tersiér, siér-siér, kakalénan, kungkulung, saluran cai'

Javanese: kulung, ulung, solokan

Betawi Malay: kalénan, solokan

TANAH SIAP TANAM 'soil ready for planting' Sundanese: léléran, siap dipelakan, geus rata', geus asak, geus caang ditanduran, arék ditanduran, geus béres, tos béres tanahna', rapih, tanuraneun, tos nanglér Javanese: léléran

Betawi Malay: léléran, tanah udah rapih, tanah udah rata'

\section{BIBIT 'seedling'}

Sundanese: bibit

Javanese: bibit

Betawi Malay: bibit

\section{BENIH 'seed'}

Sundanese: bibit, binih

Javanese: bibit, winih

Betawi Malay: bibit

BENIH BAIK 'prime seed'

Sundanese: bibit alus, bibit nu alus, bibit saé,, bibit anu saé,, bibit super, bibit unggul, berlabél, bernas, bibit mulus, bibit 
Javanese: bibit, bibit unggul, winih bagus

Betawi Malay: bibit unggul, bibit bagus, bibit

BENIH SEHAT 'healthy seed'

Sundanese: bibit, bibit alus, bibit anu alus, bibit nu alus, binih alus, bibit berlabél, berlabél, bibit nu séhat, bibit séhat, binih séhat, bibit mulus, bibit saé', bibit super, bibit unggul, inpari 20 , bernas

Javanese: bibit unggul, bibit, winih bagus

Betawi Malay: bibit unggul, bibit, bibit bagus

\section{BENIH BERSIH 'clean seed'}

Sundanese: bibit mulus, bibit saé', bibit alus, bibit nu alus, bibit anu alus, bibit nu bersih, bibit bersih, bibit beresih, bibit beuresih, bibit super, bibit unggul, bibit séhat, binih séhat, berlabél, bernas

Javanese: bibit unggul, bibit, winih bagus

Betawi Malay: bibit unggul, bibit, bibit bagus

\section{MEMILAH BENIH BAIK 'seed selection'}

Sundanese: dipilih, dipilihan, pilih pilihan, milih, milih bibit, milih binih, milahan, metik bibit, ngaléyan, misahkeun, nyortir, sortir, nyortil, micen nu hapa, dipisah

Javanese: milih bibit, milih winih, ngaléni, seléksi

Betawi Malay: milih bibit

\section{UJI BENIH BAIK 'seed trials'}

Sundanese: dicoba', mencoba', nyoba', nyoba'an, ngajajal bibit, nguji bibit, uji bibit, dipilihan, milihan, milihan binih, milihan bibit, milih bibit, ngaléyan, ngalémbang, saléksi

Javanese: ngalémbang, ngekum winih
Betawi Malay: ngetés bibit, direndem, dirimbang

\section{MERENDAM BENIH 'soaking seeds'}

Sundanese: dikeeum, dikeeum tu cai', ngeeumngeeum binih, ngeeuman, keeum, keeum bibit, dikeeumin, ngalembang, ngerendem

Javanese: ngeeum, ngekum, dikum, ngekum winih

Betawi Malay: rendem, direndem, ngerendem bibit

MENANGKARKAN BENIH 'seed cultivation'

Sundanese: ngalobakeun bibit, ngalobakeun, ngabibitkeun, dibibitkeun, pambibitan, pangbibitan, nyieun bibit, pawinian, digemuk, gugula'an, penangkaran, nangkar bibit, taker bibit, naker bibit

Javanese: nambah bibit, ngebibiti, mbibiti, tangkar

Betawi Malay: pembibitan

\section{PERSILANGAN 'cross'}

Sundanese: ngawinkeun, ngawinkeun bibit, dikawinkeun, pangbibitan, diaduk Javanese: ngawinna', ngebibiti

Betawi Malay: dikawinin, pembibitan

HIBRIDA 'hybrid'

Sundanese: turunan

Javanese: -

Betawi Malay: hibrida

MENANAM 'plant'

Sundanese: melak, tandur, nandur, tanur Javanese: tandur, nandur

Betawi Malay: nanem, tandur, nandur 


\author{
MENYEMAI 'sow' \\ Sundanese: sebar, disebarkeun, sebaran, \\ nyebar, tebar, ngawur \\ Javanese: sebar, disebarkeun \\ Betawi Malay: sebar, nyebar

\section{POLA TANAM 'cropping pattern' \\ Sundanese: pola tanam, pola', giliran paritas, taplakan, panyelang, ngolah tatangkalan, modél melak, cara melak paré, melak paré, giliran \\ Javanese: gentian, génggong, pola tanam, sistim nandur \\ Betawi Malay: pola tanam \\ JARAK TANAM 'spacing' \\ Sundanese: lega'na', lega'na tanaman, ukuran, ukuran melak, ukuran caplakan, ukuran tanam, ukuran tandur, téhelan, carang, carangna', taplakan, teplak, jauh, jauhna', jarak tanam, jarak melakna', jarakna', renggang melak, dapuran \\ Javanese: jarak nandur, jarak tanam, ukuran}

Betawi Malay: gowo', jarak tanam

TUMPANG SARI 'intercropping'

Sundanese: tumpang sari, tumpang sari', diadukkeun, melak bareng-bareng, campur-campur

Javanese: tumpang sari

Betawi Malay: cocok tanam tumpang sari, tumpang sari'

PENANAMAN JALUR TERATUR 'regular line planting'

Sundanese: tandur jajar, caplak, caplakan, naplak, taplak, taplakan, ditaplak, rapih, lempeng, kolangan, téhelan, ditéhel, logowo', okém, diokém, ngabaris, lurus, penanaman jalur teratur, rata'

Javanese: taplak, taplakan, téhelan, ditéhel
Betawi Malay: caplak, taplak

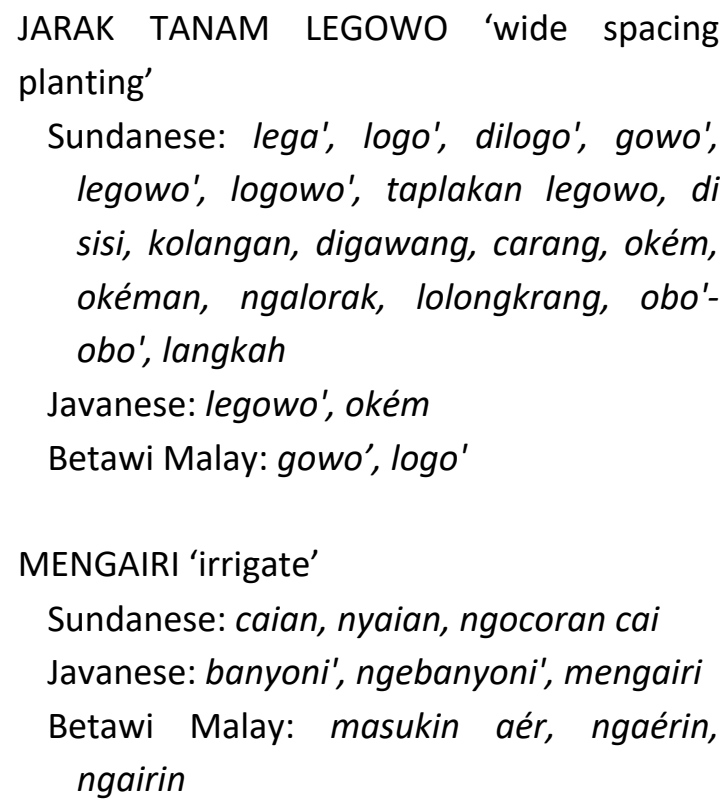

Sundanese: lega', logo', dilogo', gowo', legowo', logowo', taplakan legowo, di sisi, kolangan, digawang, carang, okém, okéman, ngalorak, lolongkrang, obo'obo', langkah

Javanese: legowo', okém

Betawi Malay: gowo', logo'

\section{MENGAIRI 'irrigate'}

Sundanese: caian, nyaian, ngocoran cai Javanese: banyoni', ngebanyoni', mengairi

Betawi Malay: masukin aér, ngaérin, ngairin

\section{MENGATUR AIR 'water management'}

Sundanese: ngatur cai', hatur cai', gilir cai', ngabagi cai', ngalilimpas, anggeran, nyaian sawah

Javanese: ngatur banyu', ngatur cai'

Betawi Malay: ngatur aér, ngatur air

MENYIANGI 'weeding rice plants

Sundanese: ngarambét, ngerambét, ngababat, ngoyos, ngabersihkan, nyaangan

Javanese: rambét, ngerambét, ngoyos

Betawi Malay: ngoyos, ngerambét

\section{MENGENDALIKAN GULMA 'weed control'}

Sundanese: dibabat, dicabutan, digasrok, dikorét, dilogram, dirambét, disemprot, semprét, nyemprot, ngoyos, ngajaga' hirupna' jukut

Javanese: rambét, dirambét, disemprot, ngoyos

Betawi Malay: disemprot, ngoyos, dibabad, nyemprot, nyemprét 


\section{MENYULAM 'replant'}

Sundanese: ayuman, ngayuman, nanjangan, nyulam

Javanese: nanjangi, nanjangan, ngayumi'

Betawi Malay: nanjangin

\section{GABAH 'grain'}

Sundanese: bangsal, bibit, gabah, paré' Javanese: gabah, gabi

Betawi Malay: gabah, gerabak

\section{BULIR 'the blossoming'}

Sundanese: tangkal, tangkal paré', cangkian, karakbeukah, beukah, paré' beukah, kereneuh, berat sangga, turiyang, ranggeuyan, ranggéyan, runggéyan, ranggeyan, paré' beuneur, leubeut

Javanese: beukah, meratak, ranggeuyan

Betawi Malay: mateng tua', kuning, meratak

PANEN 'harvest'

Sundanese: panén, ngadereupkeun Javanese: panén

Betawi Malay: panén

\section{MERONTOKKAN 'shed'}

Sundanese: dirontog, rontogan, dirontok, ngiri', digebot

Javanese: dirontok

Betawi Malay: digerabak, perontok, dirontok, disintok

MEMBUMBUN 'soil heaping'

Sundanese: gunduk, ngagunduk, digunduk, gundukan, digundukkeun, gundukkeun, diakut, dikumpulkeun, numpuk, tumpuk, ditumpuk, ditumpug, ditumpukkeun

Javanese: ditumpuk, gundukan, gundukaken, gundukna'

Betawi Malay: gundukin, tumpuk, umpukin

\section{MENGAYAK 'sift'}

Sundanese: diayak, ayak, ditapi, tapian, nginter

Javanese: diayak

Betawi Malay: nginter, diayak

\section{MENGERINGKAN 'drying'}

Sundanese: digaringkeun, dipoé', poékeun, dijemur

Javanese: digaringken, mépé'

Betawi Malay: dijemur

\section{MENGGILING 'grind'}

Sundanese: ngadésel, ngagiling, nutu', ngahéleur

Javanese: ngadésel, ngedésel, ngegiling

Betawi Malay: ngegiling, ngedésel

\section{BERAS 'rice'}

Sundanese: béas

Javanese: béas, beras

Betawi Malay: beras

BERAS PUTIH 'white rice'

Sundanese: béas, béas alus, béas bodas

Javanese: béas, beras, beras putih

Betawi Malay: beras putih

\section{BERAS PECAH 'broken rice'}

Sundanese: béas parotong, béas potong, béas potong-potong, béas gitay, gitay, béas bubuk, béas belah, beras beulah, beunyeur, béas beunyeur

Javanese: gitay, beras pecah, beunyeur, menir

Betawi Malay: beras ancur, menir

\section{BERAS BERSIH 'clean rice'}

Sundanese: béas bersih, beras beresih, béas diisikan, béas super, béas bodas, béas sosoh, béas alus, béas anu alus, béas saé', béas badag , béas poles, béas 
Javanese: béas, beras, beras bersih, beras super

Betawi Malay: beras murni, beras bersih

BERAS BERSELUBUNG 'unhulled rice'

Sundanese: gabah, gabahan, béas wuluh, béas belosoran, béas sérah, sérah, sérahan, béas aya sérahan, béas kotor, béas atah, béas péka', geneuk Javanese: beras péka', beras peka', sérah

Betawi Malay: peka'an

BERAS CAMPUR 'mixed rice'

Sundanese: -

Javanese: -

Betawi Malay: -

BERAS TUMBUK 'hand pounded rice'

Sundanese: béas tutu', béas nutu', béas ditutug, béas ditutu', béas tumbuk, béas wuluh, tipung, tipung béas

Javanese: béas tutu', beras tutu', beras tutug

Betawi Malay: beras tumbuk, beras tutu'

\section{BERAS KEPALA 'head rice'}

Sundanese: béas kepala, béas bodas, béas alus, béas saé', béas super, béas kristal, béas beunyeur, béas muncul, béas badag, béas gedé, béas poles, sérah

Javanese: béas saé, béas super, beras bagus, beras slip, beras super

Betawi Malay: beras super, beras

\section{BUTIR BERAS RETAK 'cracked grains'}

Sundanese: béas rengat, béas renteng, béas remek, béas beulah, béas beulahbeulah, béas bareulah, béas beunyeur, beunyeur, béas goréng, béas potongpotong, béas potong, béas peruh, béas rusak, ngareunteug, menir, gitay, béas rengat, béas renteng, béas remek, béas beulah, béas beulah-beulah, béas bareulah, béas beunyeur, beunyeur, béas goréng, béas potong-potong, béas potong, béas peruh, béas rusak, ngareunteug, menir, gitay

Javanese: gitay, menir

Betawi Malay: menir, beras ancur

BUTIR BERAS RUSAK 'damaged grains'

Sundanese: béas ancur, béas buruk, béas buluk, béas kawak, béas beunyeur, béas bulukan, béas hapeuk, béas goréng, béas kutoko', béas tokoan, béas supa'an, béas awon, béas arés arés, béas sembako', béas raskin, ngareunteug, béas ancur, béas buruk, béas buluk, béas kawak, béas beunyeur, béas bulukan, béas hapeuk, béas goréng, béas kutoko', béas tokoan, béas supa'an, béas awon, béas arés arés, béas sembako', béas raskin, ngareunteug

Javanese: blesak, beras buluken, béas kawak

Betawi Malay: beras raskin

BUTIR BERAS MENGAPUR 'chalky rice'

Sundanese: béas beunyeur, béas bubuk, béas kutoko', béas bulukan, béas berkapur, béas kapuran, béas biji kapur, béas goréng, béas dolog, béas ngetan, béas kumanan, hapeuk, béas heubeul, béas sembako', béas raskin

Javanese: beras blesak, beras ngapur, béas raskin, beras raskin

Betawi Malay: beras ketelatan, beras meleduk

\section{BUTIR BERAS BERNODA 'stained rice'}

Sundanese: béas arés arés, béas bahé, béas belog, béas buluk, béas goréng, béas keseun, béas kulehe', béas kumanan, béas kotor, béas kutoko', béas raskin, béas sembako', béas tokoan, hapeuk 
Javanese: beras buluken, beras kawak, beras raskin, béas raskin

Betawi Malay: beras pasaran, beras sayur

BERAS GILING LENGKAP 'complete milled rice'Sundanese: béas désel, béas héleur, béas heleran, béas giling, béas meunangagiling, béas tutu', sérah, gelosor

Javanese: béas désel, beras désel, beras déselan, beras gilingan

Betawi Malay: beras désel, beras

\section{BERAS GILING TIDAK LENGKAP' incomplete} milled rice'

Sundanese: -

Javanese: -

Betawi Malay: -

DEDAK 'bran'Sundanese: dedak, dedek, huut

Javanese: dedak, dedek

Betawi Malay: dedek

JERAMI 'straw'Sundanese: jajaba', jarami', jerami, jorami'

Javanese: damén, dami', jarami

Betawi Malay: damén

PADI 'paddy'

Sundanese: paré'

Javanese: padi', paré', pari'

Betawi Malay: padi, padi', padih

KADAR AIR 'moisture content'

Sundanese: beseuk, baseuh, basah garingna, kadar cai', kadar air, kadar aér, ukuran cai', ngukur garing, rendemén

Javanese: kadar banyu', kadar air, réndemen

Betawi Malay: berat énténg, ngandung aér, kadar aér

\section{PENYOSOHAN 'polishing'}

Sundanese: diayak, ditapi', ngisikan, disosoh, ngabodaskeun béas, ngahérangkeun, diinter, nginteran, héleur, dipéka', ngici'

Javanese: disosoh, masusi', ngici'

Betawi Malay: disosoh, ngici'

DERAJAT SOSOH 'rice polishing ratio'

Sundanese: -

Javanese: -

Betawi Malay: -

\section{BEDENG 'seed storage hut'}

Sundanese: saung, saung bibit, saungan, bédéng, kubung, blandongan, imah kasa, gugula'an

Javanese: bédéngan, gubug, gugula'an

Betawi Malay: gubuk, bédéng

\section{GARU 'harrow'}

Sundanese: garu', garu, garukan, gagarukan, garuk, garo', garok, gasrok, roéhan

Javanese: garu', garuk

Betawi Malay: garu', garukan

CANGKUL 'hoe'

Sundanese: pacul, pacul bayangangsar, pacul doran

Javanese: pacul, pacul ayam jago', pacul ceplaya'

Betawi Malay: pacul

KERBAU 'water buffalo'

Sundanese: $k e b o^{\prime}$, munding

Javanese: kebo'

Betawi Malay: kebo'

TRAKTOR BESAR 'tractor'

Sundanese: -

Javanese: - 
Betawi Malay: -

TRAKTOR TANGAN 'hand tractor'

Sundanese: bota', kubota', kaléktor, kaléktor kuik, kaléktor gelebeg, keléktor kuik, taléktor, taléktor kuik, teréktor, traktor, kuik banting, kuik belok

Javanese: keléktor, léktor kuik, léktor rotari', léktor singkal, teréktor kuik

Betawi Malay: keléktor kuik, kaléktor kuik, teléktor kuik

PERATA TANAH 'land roller'

Sundanese: dorongan, dorongan papan, dodorong, jojorong, sosorong, papan, tarik balok, pamedet, kayu, lepa'an, gagaru', garu', garu, garuk, garukan, garok, garokan, gasrokan, kekeruk, gelinding, setum, gejug, kalektor, gubuar Javanese: garokan, gubuar, kerokan

Betawi Malay: kerokan, garukan

RAK 'shelf, rack'

Sundanese: erak, rak, paratag

Javanese: rak

Betawi Malay: erak, rak

PIPA DRAINASE 'drainage pipes'

Sundanese: paralon, pralon, pipa, pipah, pipa cai', selang cai', talang, lédeng

Javanese: paralon, pipa, pipa', pipah

Betawi Malay: pralon, talang

ALAT UKUR HUJAN 'ombrometer, rain gauge'

Sundanese: -

Javanese: -

Betawi Malay: -

ARIT 'sickle'

Sundanese: arit

Javanese: arit

Betawi Malay: arit
PARANG 'knife'

Sundanese: parang, pedang, bedog

Javanese: parang, pedang

Betawi Malay: parang

ANI-ANI 'crop knife'

Sundanese: etém, étém

Javanese: ani-ani', étém

Betawi Malay: ani-ani', étém

PEMBABAT BATANG PADI 'rice cutter'

Sundanese: -

Javanese: -

Betawi Malay: -

PERONTOK GABAH 'threshing machine'

Sundanese: rontogan, rontokgan, perontok, rontog, mesin rontok, tréser, power téser, grabakan

Javanese: gerantak, grabagan, kombén, rontogan

Betawi Malay: perontok gerabak, perontok, sintog, kombén

MESIN PENGERING 'paddy dryer'

Sundanese: open, openan, opfenan, mesin open, désel, pengeringan gabah

Javanese: open, openan

Betawi Malay: open

TERPAL 'tarpaulin'

Sundanese: terpal, balibar, laburan

Javanese: terpal, gelaran, laburan

Betawi Malay: terpal

LANTAI JEMUR 'rice drying floor'

Sundanese: latar, lamporan, lataran, laburan, buruan, di lapang, teras, pamoéan, tempat moé', paragih moé' Javanese: latar, lamporan

Betawi Malay: latar, lamporan 
PENGGILING PADI 'rice huller'

Sundanese: péka', méka', désel, déselan, molen, molenan, ici', heleur, heleran, huler, gilingan, gilingan béas, gilingan paré'

Javanese: désel, huler, nyelip

Betawi Malay: désel, héler, ici'

PEMECAH KULIT GABAH 'rice husker'

Sundanese: dabrol, désel, déselan, gilingan, héler, héleur, huler, ici', icih, molen, molenan, péka', rol, rontogan

Javanese: désel, huler, nyelip

Betawi Malay: molen, désel

\section{PENYOSOH 'rice polisher'}

Sundanese: désel, déselan, gilingan, héler, heleran, heleur, héleur, ici', inci', molen Javanese: ici', nyelip

Betawi Malay: ici', désel

PENGAYAK 'rice sifter'

Sundanese: ayakan, gedogan, rontogan

Javanese: ayakan

Betawi Malay: ayakan, pengayak

BAKUL 'bamboo basket'

Sundanese: bakul, boboko', dingkul, gebog, said, tolok, tolombong

Javanese: bakul, capon, wakul

Betawi Malay: bakul

TAMPAH 'winnowing tray'

Sundanese: nyiru', nyiru, tampian, tampir Javanese: tampah

Betawi Malay: tampah, tatampah, tetampah

LUMBUNG 'rice barn'

Sundanese: gudang, kokondong, leuit Javanese: lumbung, gudang, leuit Betawi Malay: lumbung

\section{ORONG-ORONG 'mole cricket'}

Sundanese: ga'ang, gahang, orong-orong

Javanese: belalangan, anggé'-anggé', ga'ang

Betawi Malay: belalangan, orong-orong

SUNDEP 'stem larvae'

Sundanese: hama', hileud, hileud abri, hileud grayak, hileud penggérék, pecah pucuk, penggérék, penggérék batang, sundep

Javanese: sundep

Betawi Malay: penggérék, penggérék batang, sundep, hileud

\section{BELUK 'caterpillar'}

Sundanese: beluk, bebeluk, kukupu', kupukupu', penggérék, penggérék batang, beluk

Javanese: beluk, kupu-kupu'

Betawi Malay: bebeluk, kupu-kupu', étém

WERENG COKLAT 'brown planthopper'

Sundanese: bereng coklat, mikung bereng coklat, wereng coklat, wereng, coklat, hama, kungkuangan

Javanese: breng coklat, wereng coklat

Betawi Malay: bereng coklat, wereng coklat

WERENG HIJAU 'green leafhopper'

Sundanese: bangbung, hama', héjo', wereng héjo', wereng, bereng, mikung bereng héjo', bereng héjo'

Javanese: breng ijo', wereng héjo', wereng ijo'

Betawi Malay: bereng ijo'

WALANG SANGIT 'rice bug'

Sundanese: kungkang, simeud, simeut, walang sangit

Javanese: kungkang, walang sangit 
Betawi Malay: kungkang, balang sangit

\author{
KEONG MAS 'golden apple snail' \\ Sundanese: kéong, kéong emas, \\ Javanese: kiong, kiong emas, kéong mas \\ Betawi Malay: kiong emas, kéong
}

TUNGAU 'rice leaf mite'

Sundanese: bolokotongo', cecantal, ciku'ciku', kini-kini, kutu, kutu', kutu kebul, kutu daun, kutu' paré', kosim, lembing, pependayan, tungau, tongo', wereng Javanese: ciku'-ciku', kutu', kutu daun, oténg-oténg, tuma' air

Betawi Malay: agas, bereng, kutu paré', kutu kebul

\section{HAMA PUTIH 'rice caseworm'}

Sundanese: kupu-kupu bodas, kupu-kupu', kupu-kupu, kupu-kupu' kecil, kukupu bodas, hama', hama ulet, hama bodas, penggérék batang, penggérék, sundep, sundep bebeluk, beluk, bodas, caricangkas, pecah pucuk, putih palsu Javanese: beluk, kupu-kupu', penggérék Betawi Malay: berayak, kupu-kupu', hama'

\section{HAMA PUTIH PALSU 'rice leaf folder'}

Sundanese: kupu-kupu putih palsu, kupukupu coklat, kupu-kupu, kupu-kupu', kukupu', kukupu' sirama-rama, ulet daun, hileud, penggérék batang, hama', hama' hileud, hama putih palsu, hama bodas palsu, putih palsu, daun nguluntung, $H P P$

Javanese: hama putih palsu, kupu-kupu', lembing batu'

Betawi Malay: penyakit putih, kupu-kupu', hama'
KEPINDING SAWAH 'rice black bug'

Sundanese: bangbung, kungkuangan, legé, lembing, lembing batu, lembing batu', pipihi'

Javanese: lembing, batu'

Betawi Malay: kepimping, lembing

ULAT PENGGULUNG DAUN PADI 'rice leaf folder larvae'

Sundanese: hileud, hileud cau', hileud kékét, hileud engkuk, hileud daun, hileud héjo', hileud jengka, hileud grayak, ulet tentra', penggulung daun

Javanese: hiled grayak, penggulung daun, uler, ulet grayak

Betawi Malay: ulet kékét, grayak, ulet

KEPIK HIJAU 'ladybird, ladybug'

Sundanese: lembing héjo', lembing, kuangkuang, kungkuangan, kepik héjo', kepik, hama', pipihi'

Javanese: kepik, lembing ijo', oténg-oténg

Betawi Malay: bengkuang, kuangan, lembing héjo', lembing ijo'

TIKUS SAWAH 'field mouse'

Sundanese: beurit, beurit sawah

Javanese: tikus

Betawi Malay: tikus

\section{BURUNG 'bird'}

Sundanese: bangau, hayaman, manuk bondol, manu' bondol, manuk blekok, manuk péking, manu' peking, manuk goléjra', manu' piit, manuk piit, manuk mandar, tikukur

Javanese: manuk bondol, manuk cici', manuk peking, manuk pit

Betawi Malay: manuk gelatik, manuk gereja', manuk manyar, burung piit, burung bondol 


\section{GULMA 'weed'}

Sundanese: jukut, patétan

Javanese: gulma, rumput, suket, welekah

Betawi Malay: rumput

\section{TUNGRO 'rice tungro'}

Sundanese: bereng, bereng héjo', wereng, lembing, sigung, tungro, hama'

Javanese: hama', tungro, tungro', wereng

Betawi Malay: sigung, bereng

HAWAR DAUN BAKTERI 'bacterial leaf blight'

Sundanese: krésék, kerésék, hawar daun, $H D B$, penggérék, kena' penggérék, kena beluk, beluk, bebeluk, sundep, cékék, penyakit bodas, busuk padi, buruk batang, bercak, bercak daun, pecah pucuk, gapuk

Javanese: krésék, beluk

Betawi Malay: pirus

\section{HAWAR DAUN JINGGA 'red stripe'}

Sundanese: krésék, kerésék, kerésék daun, ngérésék, barereum, hama beureum, penyakit beureum, panyakit daun, bercak daun, bebeluk, gabag, HPP, hapa', kana' bereng

Javanese: bercak daun, krésék, kerésék

Betawi Malay: luncat pucuk, sundep, krésék

\section{HAWAR PELEPAH 'sheath blight'}

Sundanese: sundep, krésék, kerésék, panyakit, penyakit, busuk pelepah, busuk pelepah daun, busuk daun, buruk tangkal, buruk batang, pelepah daun, hawar, hawar pelepah, gararing, pecah pucuk, ngararas, BLB, jamuran, supa'an, lémpes, hama lilin, hama gingsir, hama lenggang, murigrik

Javanese: busuk daun, kerésék, krésék

Betawi Malay: krésék

\section{BUSUK BATANG 'stem rot'}

Sundanese: panyakit sundep, sundep, kerésék, krésék, busuk batang, busuk, buruk batang, buruk tangkal, buruk akar, buruk bedogol, buruk, baruruk, ngaburuk, panyakit, melepes, benték, lolodoh, lodoh, beureum padi, penggérék batang, kana bereng, lempeh, lempeuh tangkal, paéh tangkal

Javanese: busuk batang, jamuran, kerésék, krésék

Betawi Malay: sundep, melepes, krésék

BLAS 'rice blast'

Sundanese: barodas, bercak daun, bercak, blas, blas daun, hama bodas, jamur, geseng, krésék, kerésék, sundep, panyakit, bodas pucuk, pecah pucuk Javanese: blas, kerésék, krésék Betawi Malay: penyakit putih, krésék

\section{BERCAK DAUN CERCOSPORA 'rice} Cercospora leaf spot, narrow brown spot'

Sundanese: jamur, kena jamur, bereum daun, barereum, krésék, kerésék, koreng, bercak, bercak daun, bercak daun kolot, geseng, garing, gararing, bintik-bintik, panyakit, tarotol, totol-totol, belang, hawar daun

Javanese: hawar daun, kerésék, krésék

Betawi Malay: penyakit bereng, krésék

PADI THRIPS 'rice thrips'

Sundanese: hama', kutu, kutu', kutu daun, sigung, simet

Javanese: semut, serangga', tomkét, wereng

Betawi Malay: pepanting, hama'

BUSUK PELEPAH DAUN 'sheath rot'

Sundanese: tutung, gosong, kena wereng, krésék, kerésék, kresek, mentet, kena' 
pirus, parotong, mungkek, barereum, panyakit, penyakit, pecah pucuk, sundep, kena sundep, busuk, busuk akar, buruk batang, buruk di handap, mejen, melekététét, hapa'

Javanese: busuk léhér, kerésék, mejen, tugel

Betawi Malay: busuk, jamur, melepes, garing

\section{PENYAKIT FUSARIUM 'root rot'}

Sundanese: krésék, kerésék, kabarangas, kena' hileud daun, bercak, bercak daun, penyakit daun, panyakit, ku hama, pecah pucuk, jamur, trotol, sundep, lodoh, menong, beureum, hama beureum, pérang, kena obat rumput
Javanese: jamur, kerésék, krésék, kena' obat rumput

Betawi Malay: jamur, krésék

PENYAKIT KERDIL 'rice ragged stunt, rice grassy stunt'

Sundanese: benték, habibi', kagaringan, kerdil, kecantet, mandul, mejen, melepes, melekététét, mentét, mentet, menték, mentek, mentil, mérékététét, mungkek, ngadedet, parondok, pondok, pendek, pirus, teu bisa jangkung, teu rata

Javanese: habibi', kerdil, mejen, menték

Betawi Malay: macét, mutut, meje 